\title{
IgA nephropathy: is a new approach beyond proteinuria necessary?
}

\author{
Eduardo Gutiérrez ${ }^{1}$
}

Received: 14 December 2018 / Revised: 14 January 2019 / Accepted: 15 January 2019 / Published online: 18 February 2019 (C) IPNA 2019

"What gets us into trouble is not what we don't know. It's what we know for sure that just ain't so".

Mark Twain

\section{Proteinuria}

The amount of proteinuria continues to be one of the parameters that best correlates with the development of renal failure in any glomerular pathology. This circumstance is especially relevant when the analysis is limited to IgA nephropathy (IgAN). Although there is no prospective evidence, the influence of proteinuria on renal evolution has been strongly tested in retrospective studies with a very high number of patients after long follow-up periods [1-3].

There is a broad agreement in the nephrological world that treatment with blockade of the renin-angiotensin-aldosterone system (RAAS) is the chosen treatment in patients with IgAN and proteinuria greater than $0.5-1 \mathrm{~g} /$ day and arterial hypertension [4]. There are very few randomized, controlled trials (RCT) in IgAN, even though it is the most common glomerular disease worldwide. However, these few studies have shown a significantly better renal survival in patients treated in this way, provided that the targets of proteinuria and blood pressure are achieved [5-7]. The early antiproteinuric effect of blockade RAAS and its recognized local activity have shown a clear renal benefit in the pediatric population.

In this issue of the Pediatric Nephrology, Shima et al. [8] report the first RCT that compares the effectiveness and safety of lisinopril in monotherapy versus the combination of

Eduardo Gutiérrez

eduardogutmat90@gmail.com

1 Nephrology Department, Hospital Universiatrio 12 de Octubre, Madrid, Spain lisinopril and losartan in children with IgAN and mild proteinuria. This is a Japanese multicenter study (19 hospitals) prospective, open-label, and randomized (1:1, adjusted by age) phase II controlled conducted between 2005 and 2010 in 63 pediatric patients with biopsy-proven IgA nephropathy and mild proteinuria. The primary end-point was the rate of disappearance of proteinuria between the monotherapy group (group A) and the combination group (group B) after a follow-up of 749 and 743 days, respectively. At the end of the study, no significant differences were observed in the disappearance of proteinuria between the two groups (group A, $89.3 \%$ vs. group B, $89 \%$ ) without differences in safety either. The authors concluded that the combination of lisinopril with losartan does not provide any benefit to treatment with lisinopril alone. However, it is important to highlight that the inclusion criteria of patients can qualify these results. Only patients with mild proteinuria and renal biopsy showing minimal or focal mesangial proliferation (less than $80 \%$ glomeruli with moderate or severe mesangial cell proliferation) were included. All the enrolled patients showed an estimated glomerular filtration rate (eGFR) greater than $60 \mathrm{ml} / \mathrm{min} / 1.73 \mathrm{~m}^{2}$ and the percentage of patients with urinary protein excretion to creatinine ratio $(\mathrm{uP} / \mathrm{Cr}$ ) greater than $0.5 \mathrm{~g} / \mathrm{g}$ was $42.9 \%$ in group A and of $34.5 \%$ in group B. As a relevant data, complete remission was reached in $32.2 \%$ of patients in group A and in $45 \%$ in group B (defined as the disappearance of hematuria, a ratio $\mathrm{uP} / \mathrm{Cr}<0.2 \mathrm{~g} / \mathrm{g}$ and eGFR $>60 \mathrm{ml} / \mathrm{min} /$ $1.73 \mathrm{~m}^{2}$ ). One of the things that IgAN suffers is that there is no consistent data on the number of patients who achieved a spontaneous remission. This same group published its experience with a large series of 555 patients, of which 57 (10.3\%) achieved spontaneous remission without receiving any medication. These patients showed minor glomerular abnormalities or focal mesangial proliferation. In this study, the authors advise that physicians should consider the possibility of spontaneous remission and wait for the use of relatively aggressive immunosuppressive treatments in IgAN patients with minor glomerular abnormalities or focal mesangial proliferation [9]. Our group observed remission in $37.6 \%$ of 141 patients with 
IgAN who presented with microhematuria and proteinuria lower than $0.5 \mathrm{~g} /$ day at renal biopsy ( 59 patients treated with RAAS blockers; mean observation period 108 months) [10]. In this series, $51 \%$ of the patients were under 18 years old with a mean baseline creatinine of $0.69 \mathrm{mg} / \mathrm{dl}$ and a mean baseline proteinuria of $0.19 \mathrm{~g} / \mathrm{day}$; of this group, $40.8 \%$ achieved spontaneous remission. Currently, and in light of the few studies conducted, few nephrologists would indicate a renal biopsy in patients with isolated microhematuria or proteinuria less than $0.5 \mathrm{~g}$ /day besides microhematuria. However, there are many patients with $\operatorname{IgAN}$ that can present with these, a priori, little significant alterations. This circumstance has led some authors to coin the term "benign IgA nephropathy." In turn, there are very few solid studies that have analyzed the evolution of this type of patients with relatively benign presentation. The information on the evolution of these patients is very important to be able to establish that IgAN are progressive.

In any case, it is essential to show that the studies carried out in Southeast Asia (China and Japan) have suggested that IgAN presenting with hematuria and minimal proteinuria can behave as progressive diseases with development of proteinuria greater than $0.5-1 \mathrm{~g} /$ day in $33-46 \%$ of patients, hypertension in $26-38 \%$, and worsening of renal function in $7-24 \%$ after a median follow-up of 7-11 years [11-14]. Probably one of the great virtues and differential facts of the study, besides being an RCT, is that the diagnosis was made in school screening in more than $80 \%$ of cases and that the entire population analyzed is of Asian origin, fact of great relevance when comparing the previously described results in the Caucasian population. It is important to note that since 1974 in Japan, all children between 6 and 18 years old are included in the annual governmental screening program, circumstance that makes it a unique cohort.

\section{Genetics: the future of glomerular diseases is here}

Genome-wide association studies have identified that Asian patients present a worse clinical evolution regardless to their place of birth and despite the clinical similarities at the time of presentation when compared with the series of Caucasian patients [15-17]. These findings can be correlated with the results of two of the large RCT performed to evaluate the effect of immunosuppression in IgAN; in the STOP-Trial, the control group (Caucasian population) showed an annual glomerular filtration loss of $1.6 \mathrm{~m} / \mathrm{min} / 1.73 \mathrm{~m}^{2}$ whereas in the TESTING (Asian population), the loss was $6.8 \mathrm{ml} / \mathrm{min} /$ $1.73 \mathrm{~m}^{2}[18,19]$. A very attractive possibility is that genetic variations can justify the different outcomes of these patients. In this way, the deletion in the genes of complement regulatory proteins CFHR1-CFHR3 that confers protection against $\mathrm{IgAN}$ is very rare in the countries of Southeast Asia and much more frequent in the black population, where the incidence and prevalence of $\operatorname{IgAN}$ is much smaller.

\begin{abstract}
"Human beings are ultimately nothing but carriers passageways- for genes. They ride us into the ground like racehorses from generation to generation. Genes don't think about what constitutes good or evil. They don't care whether we are happy or unhappy. We're just means to an end for them They only thing they think about is what is most efficient for them".
\end{abstract}

Haruki Murakami

\section{Hematuria: inexplicably forgotten}

The variability and severity of glomerular manifestations in IgAN, as well as the long disease course make it difficult to predict the prognosis of patients and establish a regulated treatment. Taking as a reference the recommendations of the Kidney Disease Improving Global Outcomes (KDIGO) guidelines, the risk of progression towards end stage renal disease (ESRD) of a patient with IgAN is determined by the mean proteinuria during follow-up, glomerular filtration rate, and blood pressure [4]. Despite the fact that microhematuria is a cardinal symptom in IgAN, very little relevance has occupied as a negative prognostic factor in $\operatorname{IgAN}$, unlike the proteinuria that continues to occupy a central role. This lack of interest in microhematuria is surprising because it is a defining symptom of the pathology with very different evolution between some patients. In some patients the amount of microhematuria decreases progressively while in others, it disappears spontaneously. In this RCT, hematuria was determined by semiquantitative methods through urine test strips. In group $\mathrm{A}, 87.1 \%$ of patients presented $3+$ and in group $\mathrm{B}$ $54.8 \% 3+$ and $32.3 \% 2+$. In both groups, there was a reduction of the hematuria during the follow-up without repercussion in the renal evolution in probable relation with the favorable evolution of the whole series. A possible explanation for the disappearance of hematuria could be the recognized antiinflammatory effect of the treatment with both angiotensinconverting inhibitors (ACEIs) and angiotensin II receptor blockers (ARBs). However, Sevillano et al. have published recently a meticolous analysis of the prognostic influence of the amount of hematuria in a cohort of 112 patients with IgAN followed through an average of 14 years [20]. The amount of mean hematuria during follow-up was significantly correlated with renal evolution and its disappearance marked an evident prognostic improvement. This is probably the first study that shows that patients with proteinuria but without hematuria are not the same as patients with proteinuria and hematuria at the same time, this association clearly predicts a more ominous 
prognosis. Therefore, hematuria should be an element to evaluate in patients with IgAN and should be used to select patients with more aggressive behavior for their inclusion in future RCTs with immunosuppressants.

\section{Histology: already recognized cornerstone}

On the other hand, histology has gained great importance in the wake of the recent Oxford Classification. This classification has also shown its validity in the pediatric population and maintains its ability to predict renal prognosis independently [21-24]. Shima et al. have made a great effort to reclassify patients according to this classification. Histologically, the patients did not show significant lesions of mesangial proliferation, no patient presented endocapillary proliferation, and tubulo-interstitial damage was also very scarce. Nevertheless, and as in the Spanish series, a significant percentage of patients had segmental and focal hyalinosis lesions. Moreover, the percentage of crescents was higher than expected with more than $50 \%$ of the patients showing $\mathrm{C} 1$ lesions according to the new Oxford Classification (MEST-C) [25].

Although the clinical behavior of patients can be defined as "benign," some of the histological findings can be used for early identification of children at risk of progression of kidney disease. Due to the fact that most patients are diagnosed in school screening, it is likely that many patients will be diagnosed in the early stages of the disease. The VALIGA (European Validation Study of the Oxford Classification of IgAN) included 261 children and young adults [26]. The children enrolled were patients with mild proteinuria and some acute glomerular lesions, features very similar to those of the Japanese cohort. In this series, children aged $<16$ years old without mesangial hypercllularity (M0) and eGFR $>90 \mathrm{ml} /$ $\min / 1.73 \mathrm{~m}^{2}$ have a high probability of proteinuria remission during follow-up. In conclusión, the Oxford Classification appears to be valid for predicting renal outcome in children and crescents are an independently significant factor for renal survival.

In this RCT of Shima et al., more than $80 \%$ of the patients were rebiopsied after approximately 24 months of follow-up, demonstrating a reduction in proliferative lesions (M1 and $\mathrm{C} 1$ ) with an increase in scar lesions of segmental and global sclerosis. This histological information gives the study one of its main strengths and reflects that the timing of renal biopsy may significantly affect the variables in the Oxford Classification [27].

\section{Conclusions}

This is a very important study but with some weaknesses that must be highlighted, (a) the sample size calculated of 110 patients was not reached, (b) the follow-up time was short, and (c) the patients included in the trial had a relatively clinical profile "benign" which can lower the conclusions about the usefulness of combined treatment with ACEI + ARB. On the other hand, it is the first RCT study that evaluates the combination of ACEI + ARB in the pediatric population. The safety profile of the combination, at the maximum authorized doses, was excellent. We can affirm with this study that this therapeutic combination is not effective in this group of patients with IgAN. In turn, we must emphasize that no patient in the study developed ESRD, which is not a justification for this type of patients should not be followed routinely by the nephrologist considering their chances of progression.

In summary, this trial shows that the NIgA approach should be changed by incorporating models to identify combined clinical (proteinuria, hematuria, eGFR...), histological (MEST-C, C4d...), and genetic risk factors for disease progression.

Publisher's note Springer Nature remains neutral with regard to jurisdictional claims in published maps and institutional affiliations.

\section{References}

1. Reich HN, Troyanov S, Scholey JW, Cattran DC, Toronto Glomerulonephritis Registry (2007) Remission of proteinuria improves prognosis in IgA nephropathy. J Am Soc Nephrol 18:31773183

2. Donadio JV, Bergstralh EJ, Grande JP (2002) Proteinuria patterns and their association with subsequent end-stage renal disease in IgA nephropathy. Nephrol Dial Transplant 17:1197-1203

3. Bartosik LP, Lajoie G, Sugar L, Cattran DC (2001) Predicting progression in IgA nephropathy. Am J Kidney Dis 38:728-735

4. Kidney Disease Improving Global Outcomes (KDIGO) Glomerulonephritis Work Group (2012) KDIGO, clinical practice guideline for glomerulonephritis. Kidney Int Suppl 2:209-217

5. Praga M, Gutiérrez E, González E, Morales E, Hernández E (2003) Treatment of IgA nephropathy with ACE inhibitors: a randomized and controlled trial. J Am Soc Nephrol 14:1578-1583

6. Coppo R, Peruzzi L, Amore A, Piccoli A, Cochat P, Stone R, Kirschstein M, Linné T (2007) IgACE: a placebo controlled, randomized trial of angiotensin-converting inhibitors in children and young people with IgA nephropathy and moderate proteinuria. J Am Soc Nephrol 18:1880-1888

7. Van den Belt SM, Heerspink HJL, Gracchi V, de Zeeuw D, Wühl E, Schaefer F, ESCAPE Trial Group (2018) Early proteinuria lowering by angiotensina-converting enzyme inhibition predicts renal survival in children with CKD. J Am Soc Nephrol 29:2225-2233

8. Shima Y, Nakanishi K, Sako K, Saito-Oba M, Hamasaki Y, Hataya H, Honda M, Kamei K, Ishikura K, Ito S, Kaito H, Tanaka R, Nozu K, Nakamura H, Ohashi Y, Iijima K, Yoshikawa N; Japanese Study Group of Kidney Disease in Children (JSKDC) (2018). Pediatr Nephrol. https://doi.org/10.1007/s00467-018-4099-8

9. Shima Y, Nakanishi K, Hama T, Mukaiyama H, Togawa H, Sako M, Kaito H, Nozu K, Tanaka R, Iijima K, Yoshikawa N (2013) Pediatric Nephrol 28:71-76

10. Gutiérrez E, Zamora I, Ballarín JA, Arce Y, Jiménez S, Quereda C, Olea T, Martínez-Ara J, Segarra A, Bernis C, García A, Goicoechea 
M, García de Vinuesa S, Rojas-Rivera J, Praga M and for the Grupo de Estudio de Enfermedades Glomerulares de la Sociedad Española de Nefrología (GLOSEN) (2012) Long-term outcomes of IgA nephropathy presenting with minimal or no proteinuria. J Am Soc Nephrol 23:1753-1760

11. Lai FM, Szeto CC, Choi PC, Li PK, Chan AW, Tang NL, Lui SF, Wang AY, To KF (2000) Characterization of early IgA nephropathy. Am J Kidney Dis 36:703-708

12. Szeto CC, Lai FM, To KF, Wong TY, Chow KM, Choi PC, Lui SF, Li PK (2001) The natural history of immunoglobulin a nephropathy among patients with hematuria and minimal proteinuria. Am J Med 110:434-437

13. Li PK, Ho KK, Szeto CC, Yu L, Lai FM (2002) Prognostic indicators of IgA ne- phropathy in the Chinese - clinical and pathological perspectives. Nephrol Dial Transplant 17:64-69

14. Koyama A, Igarashi M, Kobayashi M (1997) Research Group on Progressive Renal Diseases: natural history and risk factors for immunoglobulin A nephropathy in Japan. Am J Kidney Dis 29:526532

15. Feehally J, Farrall M, Boland A, Gale DP, Gut I, Heath S, Kumar A, Peden JF, Maxwell PH, Morris DL, Padmanabhan S, Vyse TJ, Zawadzka A, Rees AJ, Lathrop M, Ratcliffe PJ (2010) HLA has strongest association with IgA nephropathy in genome-wide analysis. J Am Soc Nephrol 21:1791-1797

16. Gharavi AG, Kiryluk K, Choi M, Li Y, Hou P, Xie J, Sanna-Cherchi S, Men CJ, Julian BA, Wyatt RJ, Novak J, He JC, Wang H, Lv J, Zhu L, Wang W, Wang Z, Yasuno K, Gunel M, Mane S, Umlauf S, Tikhonova I, Beerman I, Savoldi S, Magistroni R, Ghiggeri GM, Bodria M, Lugani F, Ravani P, Ponticelli C, Allegri L, Boscutti G, Frasca G, Amore A, Peruzzi L, Coppo R, Izzi C, Viola BF, Prati E, Salvadori M, Mignani R, Gesualdo L, Bertinetto F, Mesiano P, Amoroso A, Scolari F, Chen N, Zhang H, Lifton RP (2011) Genome-wide association study identifies susceptibility loci for IgA nephropathy. Nat Genet 43:321-327

17. Kiryluk K, Li Y, Sanna-Cherchi S, Rohanizadegan M, Suzuki H, Eitner F, Eitner F, Snyder HJ, Choi M, Hou P, Scolari F, Izzi C, Gigante M, Gesualdo L, Savoldi S, Amoroso A, Cusi D, Zamboli P, Julian BA, Novak J, Wyatt RJ, Mucha K, Perola M, Kristiansson K, Viktorin A, Magnusson PK, Thorleifsson G, Thorsteinsdottir U, Stefansson K, Boland A, Metzger M, Thibaudin L, Wanner C, Jager KJ, Goto S, Maixnerova D, Karnib HH, Nagy J, Panzer U, Xie J, Chen N, Tesar V, Narita I, Berthoux F, Floege J, Stengel B, Zhang H, Lifton RP, Gharavi AG (2012) Geographic differences in genetic susceptibility to IgA nephropathy: GWAS replication study and geospatial risk analysis. PLoS Genet 8:e1002765

18. Sevillano AM, Gutiérrez E, Yuste C, Cavero T, Mérida E, Rodríguez P, García A, Morales E, Fernández C, Martínez MA, Moreno JA, Praga M (2017) Remission of hematuria improves renal survival in IgA nephropathy. J Am Soc Nephrol 28:30893099

19. Working Group of the International IgA Nephropathy Network and the Renal Pathology Society, Coppo R, Troyanov S, Camilla R, Hogg RJ, Cattran DC, Cook HT, Feehally J, Roberts IS, Amore A, Alpers CE, Barrat J, Berthoux F, Bonsib S, Brujin JA, D'Agati V, D’Amico G, Emancipator SN, Emma F, Ferrario F, Fervenza FC,
Florquin S, Fogo AB, Geddes CC, Groene HJ, Haas M, Herzenberg AM, Hill PA, Hsu SI, Jennette JC, Joh K, Julian BA, Kawamura T, Lai FM, Li LS, Li PK, Liu ZH, Mezzano S, Schena FP, Tomino Y, Walker PD, Wang H, Weening JJ, Yoshikawa N, Zhang H (2010) The Oxford IgA nephropahty clinico- pathological classification is valid for children as well as adults. Kidney Int 77:921-927

20. Shima Y, Nakanishi K, Hama T, Mukaiyama H, Togawa H, Hashimura Y, Kaito H, Sako M, Iijima K, Yoshikawa N (2012) Pediatr Nephrol 27:783-792

21. Shima Y, Nakanishi K, Hama T, Sato M, Mukaiyama H, Togawa H, Tanaka R, Kaito H, Nozu K, Iijima K, Yoshikawa N (2015) Pediatr Nephrol 30:293-299

22. Coppo R, Lofaro D, Camilla RR, Bellur S, Cattran D, Cook HT, Roberts IS, Peruzzi L, Amore A, Emma F, Fuiano L, Berg U, Topaloglu R, Bilginer Y, Gesualdo L, Polci R, Mizerska-Wasiak M, Caliskan Y, Lundberg S, Cancarini G, Geddes C, Wetzels J, Wiecek A, Durlik M, Cusinato S, Rollino C, Maggio M, Praga M, K Smerud H, Tesar V, Maixnerova D, Barratt J, Papalia T, Bonofiglio R, Mazzucco G, Giannakakis C, Soderberg M, Orhan D, Di Palma AM, Maldyk J, Ozluk Y, Sudelin B, Tardanico R, Kipgen D, Steenbergen E, Karkoszka H, Perkowska-Ptasinska A, Ferrario F, Gutierrez E, Honsova E. (2017) Risk factors for progression in children and young adults with IgA nephropathy: an analysis of 261 cases from the VALIGA European cohort. Pediatric Nephrol 32:139-150

23. Trimarchi H, Barratt J, Cattran DC, Cook HT, Coppo R, Haas M (2017) Oxford Classification of IgA nephropathy 2016: an update from the IgA Nephropathy Classification Working Group. Kidney Int 91:1014-1021

24. Coppo R, Troyanov S, Bellur S, Cattran DC, Cook HT, Feehally J, Roberts IS, Morando L, Camilla R, Tesar V, Lunberg S, Gesualdo L, Emma F, Rollino C, Amore A, Praga M, Feriozzi S, Segoloni G, Pani A, Cancarini G, Durlik M, Moggia E, Mazzucco G, Giannakakis C, Honsova E, Sundelin BB, Di Palma AM, Ferrario F, Gutierrez E, Asunis AM, Barratt J, Tardanico R, PerkowskaPtasinska A; VALIGA study of the ERA-EDTA Immunonephrology Working Group (2014) Validation of the Oxford classification of IgA nephropathy in cohorts with different presentations and treatments. Kidney Int 86:828-836

25. Coppo R, Davin JC (2015) The difficulty in considering modifiable pathology risk factors in children with IgA nephropathy: crescents and timing of renal biopsy. Pediatr Nephrol 30:189-192

26. Rauen T, Eitner F, Fitzner C, Sommerer C, Zeier M, Otte B, Panzer U, Peters H, Benck U, Mertens PR, Kuhlmann U, Witzke O, Gross O, Vielhauer V, Mann JF, Hilgers RD, Floege J; STOP-IgAN Investigators (2015) Intensive supportive care plus immunosuppression in IgA nephropathy. N Engl J Med 373:2225-2236

27. Lv J, Zhang H, Wong MG, Jardine MJ, Hladunewich M, Jha V, Monaghan H, Zhao M, Barbour S, Reich H, Cattran D, Glassock R, Levin A, Wheeler D, Woodward M, Billot L, Chan TM, Liu ZH, Johnson DW, Cass A, Feehally J, Floege J, Remuzzi G, Wu Y, Agarwal R, Wang HY, Perkovic V; TESTING Study Group (2017) Effect of oral methylprednisolone on clinical outcomes in patients with IgA nephropathy: the TESTING Randomized Clinical Trial. JAMA 318:432-442 